\title{
Criticism of Colonialism and the Colonial Memory Work in
}

\section{Germany}

\author{
Jacob Emmanuel Mabe \\ Chairman of the Anton Wilhelm-Amo Society, Berlin, Germany
}

\begin{abstract}
Colonialism is an ideological system that was not only contrary to traditional African law (family law, popular law, etc.), but was also incompatible with the dignity of man. Colonial tyranny in Africa began with the political implementation of the decisions adopted at the Berlin Conference of 1884/85, its essential principles of international law being the inviolability and the purity of colonial borders. Thus the European colonial powers managed to avoid wars of aggression and prevent uprisings by African people. Since the dominant theories of colonialism were Eurocentric, they could scarcely contribute to adequately investigating the nature of colonialism, let alone adequately describing its dimension in Africa. Instead of examining the shades of the colonial system from different cultural perspectives to inform people objectively, Eurocentric theories prevented any attempt at truth about colonial injustice. Unfortunately, some Europeans still tend to endorse the colonial injustice system in Africa with cheap and cynical Downplaying terms. The fact that colonial policy has a long history, however, in no way indicates that it should necessarily be accepted or legitimized. On the contrary, since its inception colonialism met with violent and intellectual opposition until African countries attained national sovereignty and territorial integrity. This article demonstrates the significance colonialism has in Africans' intellectual discourse and shows how the colonial question is discussed in Germany.
\end{abstract}

Keywords: Colonialism, Pan-Africanism, Eurocentrism, Memory work, pessimism, optimism

\section{Introduction}

The term "colonialism" is over-used today and is connected with almost every military and administrative presence in a foreign country. But colonialism generally refers to a state's political ambition to annex other people's social and cultural areas of life in order to subject them to its authority and rule. The colonial moment is expressed not only through the simple unilateral extension of sovereignty and territorial rights, but also through economic exploitation, land expropriation, denial of the right to self-determination, etc.

In Africa, colonialism refers to the political systems established by France, England, Spain, Portugal, Germany, and Italy that involved violent occupation and the exercise of power overseas sanctioned by legality. Colonial tyranny in Africa began with the political implementation of the decisions adopted at the Berlin Conference of 1884/1885, its essential principles of international law being the inviolability and the purity of colonial borders (Falola, 2001/2004). Thus, the European colonial powers managed to ban wars of aggression and prevent uprisings by African people.

Prof. Dr. Dr. Jacob Emmanuel Mabe, philosopher and political scientist, chairman of the Anton Wilhelm Amo Society, Berlin, Germany. 
The fact that colonial policy has a long history, however, in no way indicates that it should necessarily be accepted or legitimised. On the contrary, since its inception colonialism met with violent and intellectual opposition until African countries attained national sovereignty and territorial integrity. This article demonstrates the significance which colonialism has in Africans' intellectual discourse and shows how the colonial question is discussed in Germany (Mabe, 2013).

\section{The Critics of Colonialism From the African Perspective Since the Beginning of the Pan-African Idea}

The intellectual criticism of colonialism began around the end of the 19th century with the idea of Pan-Africanism (Martin, 1985; Esedebe, 1994; Fierce, 1993), which had the goal of raising the awareness of all peoples of African origin worldwide of the ruthless territorial usurpations and occupations of the Europeans in Africa, and to make them feel equally concerned by them. The Pan-Africans strove for the freedom and unity of all the peoples of Africa, perceived colonialism as a barbaric and at the same time illicit act, which according to their conviction could only be ended by the common action of all historically aware people professing cultural ties with Africa.

Historically, Pan-Africanism went back to a minority of Africans living in America, who had already founded the Back to Africa Movement and in this way wished to convince their compatriots, due to the unhindered and continuous racist discrimination, to return to Africa. This movement culminated in the founding of the Republic of Liberia in 1879 through the first returners. However, the term "Pan-Africanism" itself dates back to the "African Association" founded in 1897 by Henry Sylvester William (1869-1911) from Trinidad, which addressed the task of providing legal assistance for Africans living in Great Britain with the solution of their problems. As a lawyer in London, Sylvester even advised official delegations from Africa visiting the British crown on general questions of colonial law. In this way, he became aware of the critical position of the African peoples in relation to the colonial powers' policy of dispossession. Hence, in 1900, he decided to organise a conference bearing the name "Pan-African Conference", which endeavoured to find strategies particularly for the protection of land. This was led to international solidarity for the promotion of the cultural and political emancipation of all black peoples.

The fact that the Afro-Americans prepared the way for the African ideology is witnessed by the involvement of figures, such as Edward Wilmot Blyden (1832-1912), William Edward Burghardt Du Bois (1868-1963), Marcus Garvey (1887-1940), etc. They were convinced that it was only academic understanding would make it possible to fight the tyranny of colonialism at its roots, which in turn were connected with philosophical, economic, political, and social theories (e.g., racial ideologies, etc.). In this way, the Pan-Africanism became the only academic ideology in favour of African emancipation.

Considered philosophically, Pan-Africanism has since served as an epistemology, i.e., a theory which has aided comprehension of African issues of life and existence, and on the other hand, as a set of ethics which sought to find the best rules and principles of action in dealing with colonial law and injustice, as well as with unrighteousness (Mabe, 2010; 2014).

From 1920 onwards, the intellectual discourse on colonialism was enriched by the entirely new concept of Négritude, which was no longer an "intellectual import", and which quickly advanced to become the most important philosophical and academic category to decisively determine Africa's process of emancipation over decades. 
Originally, Négritude (Irele, 1990) was conceived as an affirmation of the African being. Its goal was to strengthen the self-confidence of the blacks suffering from colonialism and racism, who were victims of discrimination, oppression, and humiliation. Although the Martinican Aimé Césaire created the word Négritude, it is nonetheless the Senegalese Léopold Sédar Senghor who gave it its theoretical meaning. Both attempted, on a poetic foundation, to create a philosophical platform for the promotion of the African consciousness. They were the first to understand colonialism as also being a racist phenomenon. With their conceptualisation of the issue of race, Senghor and Césaire anticipated almost all the philosophical reflections on colonialism and neo-colonialism, and hence shaped the intellectual discourses of African modernity. In summary, Négritude was understood as:

(a) A literary current which united all writers and poets of African origin in the battle against European racism, and itself was not constructed on the basis of racism, but rather promoted common humanity and peaceful coexistence between the peoples.

(b) A cultural theory which had the goal of strengthening the consciousness of blacks of their culture and their African origin.

(c) A political ideology which strove for the unity of all blacks in the battle against the cultural dominance of the whites.

After 1945, the intellectual debates were no longer solely literary, but with Kwame Nkrumah and Frantz Fanon also took the shape of a new form of political and academic criticism. Unfortunately, the heads of state, who were themselves very involved in the anti-colonialist battle, neglected to construct a national and continental platform for intellectual debates immediately after the phase of dependency (1956-1961). They would only have needed to create the legal foundations to consistently promote dialogue between Africans on all issues concerning their continent, in the search for potential solutions for them. What is meant here is the legal foundations for free expression of opinion on political, cultural, social, religious, and economic issues? In this way, the path would no doubt have been cleared for the continuous education of competent leading figures, who today would be able to face the national and global challenges confidently. The situation of Africa would also doubtless be different in many areas today. Instead, a hunt was launched on free-thinking artists and academics. Hence up to the present day, they, with their critical comments, are not infrequently exposed to religious and political persecution in some countries.

If the fear of intellectuals has clearly receded in the meantime, nonetheless resentment against them is still rife, as they are often made into scapegoats for the negative image of Africa. While the opposition parties in the intellectuals' homeland flirted with them for tactical reasons, the established powers always viewed every form of intellectual activity highly sceptically, even stoking fears against them politically. The intellectuals themselves, however, do not see their activity as an act of superiority, but exclusively as a verbal contribution to the improvement of the cultural existence of humans. Hence, three categories of African intellectuals to date can be distinguished, who position their experience of colonialism and its effects in different ways and with different arguments. ${ }^{1}$

The first category is that of the optimists, who generally support an approach free of prejudices both towards European culture and toward the colonial past. They also demand reconciliation through cultural

\footnotetext{
1 Jacob Emmanuel Mabe, Vom kollektiven Gedächtnis zur Konvergenzhistorik. Afrikanische und europäische Erinnerungen an den Kolonialismus philosophisch hinterfragt (Munich 2006). Das Unrecht erinnern. Der moderne Diskurs über den Kolonialismus in Afrika, in INKOTA-Brief (Zeitschrift zum Nord-Süd-Konflikt und zur konziliaren Bewegung, 149/2009), 12-14.
} 
dialogue as well as economic cooperation, and they warn against always demonising European models or blaming the Europeans for all the undesirable developments in the respective African countries. For the optimists, there is no alternative for the cultural, economic, and technical progress of Africa other than forging ties with the West through the acquisition of its values. The optimists have subjected themselves passively not only to colonialism, but also to the current neo-colonialism as well as globalisation.

The second category encompasses the pessimists, who not only see colonialism as being responsible for the disempowerment and desacralisation of African cultures and traditions, but also criticise it in all its forms. The pessimists justify their position with the argument that it is the Europeans who, without any provocation and of their own accord, came to Africa in order to intentionally kill the people living there, to drive them out of their home and homeland, or to subject them to their power and authority. In their view, colonialism led to the creation of societal situations which were not only against traditional unwritten law (family law, people's rights, etc.), but were also incompatible with human dignity. The pessimists distrust European theories and models of thought not least because to date they have scarcely contributed towards an adequate investigation by the West of the nature of colonialism, let alone describing its dimensions appropriately.

According to the view of the pessimists, the cultural ideas from Europe prevent any search for truth on colonial injustice. Finally, the pessimists uncompromisingly refuse to adapt to the Western system, insofar as it may lead to the Europeans intentionally driving the African continent into cultural, political, and economic crisis, in order to make its elites intellectually and financially dependent on them and hence to manipulate over a long period of time. They therefore see no difference between colonialism and neo-colonialism, because the latter is also based on greed for profit, selfishness, and unscrupulous exploitation, and serves exclusively to secure the prosperity of the rich industrial countries at the cost of weaker states of Africa. In the view of the pessimists, independent development of Africa is only possible through a distancing from Western ideologies together with a simultaneous retrospective reflection on African roots. This, however, does not mean a relapse into an atavistic and unknown tradition. All that is desired is to counteract the increasing historical illiteracy, particularly in young Africans, by making them able to understand and value the authentic ethical and metaphysical values of Africa.

The third category is that of the neutralists, also called the neo-optimists, who neither oppose an association with the West nor support a dissociation of Africa from it. What is of decisive importance for Africa, from the point of view of the neo-optimists, is not the question of the origin of a model of thought, but rather whether this model is suitable to promote the economic and technical progress of the countries of Africa? They warn not least against political compromises and dogmatic positions in Africa which lead to unnecessary stagnation or loss of time. The neutralists wish to mediate between the rival tendencies, in order to move them towards an objective discussion. They therefore warn against all blind optimism, as well as against intransigent pessimism, because both positions can change respectively into an irrational illusion. Instead, they recommend realism and objectivism.

What logic, then, does the intellectual discourse have? The logic is connected with the goal of reaching a societal consensus that the undesirable developments and problems of the countries of Africa, individually or collectively, are not subject to natural laws which cannot be captured or explained with the African mind. The logic of the discourse also aims to effectively use the intellectual potential of Africans for economic, political, and social purposes. 


\section{Colonialism in the Remembrance Debates of the Germans}

While critical discussions relating to colonialism continue in Africa openly and almost without any taboos, scarcely any intensive and factual consideration of the colonial past takes place in Germany in particular. The shameful events dating from the colonial period were either for a long time reported to the public in an overly one-sided Eurocentric manner, or were simply concealed. It therefore remains a great failing, particularly on the part of academics, that many colonial issues have not been dealt with comprehensively.

The fact that the German Empire was a colonial power (1884-1918) and had territorial holdings in Cameroon, East Africa (present-day Tanzania), South-West Africa (present-day Namibia) and Togo, and the remembrance of this period, was erased in many Germans' memory a long time ago, particularly after the Second World War. Particularly, the intensive occupation since 1945 with the brutal experiences during National Socialist dictatorship brought about a general tendency to forget other historical periods and events, including the colonial past.

In general, the attitudes of the Germans towards colonial history as early as the period of German division (1949-1990) were emotional rather than rational, and therefore continually through the various reports presented by the media. However, the significance which is currently assigned to colonialism also depends essentially on the image of Africa which is conveyed by the information and communication media. It can be derived from the current situation that with respect to colonial consciousness of remembrance, the Germans have a trivalent relationship with Africa:

- First, Africa remains an unforgotten continent for the Germans insofar as its geographical division, which is valid up to today, was carried out in 1884/1885 in Berlin, the capital of Germany. This historical event, which has engraved itself firmly in the memory of history-conscious Germans, partly determines their emotional attitude towards Africa. Hence, they often tend to attribute most conflicts and wars between African ethnic groups to the colonial frontiers drawn up in the continent.

- Secondly, Germany owes its historical reputation as a colonial power to its overseas possessions, particularly in Africa. Germans who are aware of this fact are highly sensitive regarding the problems in Cameroon, Namibia, Tanzania, and Togo, and gladly support projects of the state, the church and private organisations in Africa which promote development.

- Thirdly, Africa is the place in which the German Empire, through the loss of its colonies during the First World War, is thought to have shown its first weakness in world politics. In memory of this "bitter" experience, all Germany governments, in the author's opinion, have taken a hesitant and very reticent position on any foreign political or military involvement in Africa in particular. ${ }^{2}$

These three aspects are, in any case, a concise presentation of the components of German remembrances of Africa as a colonial scene. What was seen as a reason for suppression of the past between 1918 and 1945, ${ }^{3}$ namely the feeling of shame-caused not by the crimes committed against Africans, but by inferiority compared with England and France in the competition for the colonies-should have no more legitimacy in a modern Europe.

\footnotetext{
${ }^{2}$ However, the experiences of defeat in the Second World War and the associated human losses also strengthened the foreign political reticence of the Germans.

${ }^{3}$ On 28 June 1918 in Versailles, the end of the German colonial empire was sealed in international law, and the colonial areas of East Cameroon and Togo were transferred to France, West Cameroon and Tanzania to the United Kingdom, and Rwanda and Burundi (even if they are not always well-known as German colonies) to Belgium.
} 
In the question of German involvement in the colonisation of Africa, opinions vary: The historical patriots, who are convinced advocates of European civilisation and German nationalism, contrast with the historical humanists, who decry without any compromise the territorial annexing of African regions, and place Germany on the same level as other colonial powers.

The historical patriots, for their part, defend an extremist Eurocentric and at the same time a very contradictory position: On the one hand, they assume a homogeneous European civilisation contrasting with highly heterogeneous and fragmented living environments in Africa, which according to their firm conviction were very foreign and closed to the Europeans. They see every form of colonial intervention in Africa as the only appropriate method to disseminate and assert European civilisation. ${ }^{4}$ Hence, Germany, according to the view of the historical patriots, had merely provided its contribution towards civilisation. On the other hand, for the patriots, the Germans were unfortunate victims of colonial history, insofar as they lost all overseas areas through their defeat in the war, and hence were no longer able to carry out their civilising task completely.

The category of historical patriots includes academics as well as adventurous travellers, business migrants, and missionaries, whose books report almost exclusively of courageous and heroic achievements of the Germans in the colonies. ${ }^{5}$ They attribute the failure of Europe's civilising mission exclusively to the heterogeneity of the cultures and peoples of Africa. The historical patriots do not even mention the gravest errors of colonial policies, such as genocides, forced labour, dispossession of land, displacement, exploitation, etc., or simply exclude them. In this way, they have constructed a monolithic system of suppressing the past, rendering colonialism harmless, and exorcising injustice, with which they either falsify every form of academic objectivity or subject it to the Eurocentric subjectivism.

For the humanists, however, the German Empire was indisputably a colonial power, admittedly not from its proclamation in 1871, but from the 1884/1885 Congo Conference in Berlin onwards, up to the end of the First World War in 1918. Hence, they argue in favour of carrying out the remembrance debates in a manner which is free of ideology and without excessive patriotic feeling, so that the colonial phase enters into people's consciousness as an unerasable period in German history. In their investigations, the humanists study some realities and even follow some obscene issues (about genocides, etc.), without concealing the guilt of Germany in the crimes and cruelties practised in Africa (Gründer, 2004; Eckert, 2014).

In recent years, historical humanists have presented some very brilliant and value-neutral studies which do justice to both European and, in part African epistemic interests. It is thanks to them that increasingly young people no longer interpret colonial events solely with cynical metaphors. They have thereby learnt their lessons from the archaic Eurocentric handling of history and the accompanying principle of the subordination of objectivity under patriotic emotional thinking. It is to the credit of the Historical Humanists not only that colonialism is gradually being incorporated into current debates of remembrance, but also that it has become an interdisciplinary research field on which philosophers, linguists, and ethnologists with different methods and

\footnotetext{
${ }^{4}$ Historical Patriotism began with the arguments in support of European imperialism and colonialism. Their most important ideological precursors were, among others, Friedrich Gotthardt Karl Ernst Fabri (1824-1891) and Wilhelm von Hübbe-Schleiden (1846-1916). While many entrepreneurs, missionaries and academics openly identified with this theory between 1918 and 1939 , today no German dares to profess it publicly.

5 The interesting book of Leo Frobenius also entirely excludes the cruelties of the colonial administration: Frobenius, Unter den unsträflichen Äthiopen (Berlin, 1913); in many books, the "colonial heroes” are remembered with pleasure such as Paul Emil von Lettow-Vorbeck (1870-1964), who as General is said to have gained victory over the English troops in the First World War in East Africa.
} 
positions are working together. ${ }^{6}$

However, a true discipline of remembering which is intended to do justice to its ethics and its historical task can only be the product of egalitarian cooperation between African and European researchers. The future discipline of remembering will have three important functions:

(a) A synthetic and communicative function consisting of balancing and reconstructing the negative and positive impulses of the colonial period such that they can be presented in a clear schema of interpretation.

(b) A retrospective function which makes a comprehensible chronological historical view on colonial events possible

(c) A prospective function, which aims to continue researching on colonialism, so that it does not disappear from people's collective memory even in the future.

\section{Closing Remarks}

While remembrance discourses on colonialism have been led very marginally by a minority of ethnologists and historians, they take place in Africa in poetry, philosophy, theology, literature, art, etc. However, in the process, Africans reflect critically both on European politics and civilisation and on orally transferred modes of life. With this bivalent methodical reflection, they associate the hope of finding objective answers to the issues: (a) of increasing social inequality and injustice; (b) on the unhampered exploitation of the natural human resources of Africa; (c) on the continuing practice of the right of the stronger party, etc.

The processing of the colonial past is now taking place in Germany. Especially in the historical sciences, colonial history and postcolonial theory are growing fields of research in which the colonial backgrounds, in particular the medical collections at German university hospitals, are worked up. Even the school history books take up colonial violence and colonial wars as topics. In addition, the demand for the repatriation of human remains, for example to Namibia, plays an important role in the public memory culture. Also expected is an official apology for the genocide of the Herero and Namas. Last but not least, clubs and other NGOs are actively working to rename street names that have been named after representatives of colonial rule. It remains to be hoped that the German colonial remembrance work will henceforth be promoted as a prerequisite for the reconciliation between Germany and the former colonial territories.

\section{References}

Eckert, A. (2014). Geschichte des deutschen Kolonialismus. Munich: C. H. Beck.

Esedebe, P. O. (1994). Pan-Africanism: The idea and movement, 177-1991. Wasington, D.C.: Howard University Press.

Falola, T. (2001/2004). Kolonialismus. In J. E. Mabe (Ed.), Das Afrika-Lexikon. Ein Kontinent in 1000 Stichwörtern (pp. 301-306). Stuttgart and Wuppertal: JB Metzler ans Peter Hammer..

Fierce, M. C. (1993). The Pan-African idea in the United States, 1900-1919: African-American interest in Africa and the interaction with West Africa. New York: Garland Publishing.

Gründer, H. (2004). Geschichte der deutschen Kolonien. Stuttgart: Schöningh UTB.

\footnotetext{
${ }^{6}$ The topic of remembrance is largely overlaid by debates on National Socialist and Communist dictatorship. In this context, we may call to mind the discussion triggered by the former president Richard von Weizsäcker in his speech of 8 May 1986, when he declared, "Whoever does not want to remember inhumanities becomes prone to new dangers of infection," or the speech by Federal President Roman Herzog "Remembrance must not end" on 27 January 1996, which was held on the "Day of Remembrance of the Victims of National Socialism”. Moreover, it is astonishing that the most recent standard books on German places of remembrance simply leave out the colonial locations. See for instance Hahn/Hahn, Die Vertreibung im deutschen Erinnern. Legenden, Mythos, Geschichte (Paderborn, 2010); Constance Carcenac-Lecomte at al., Deutsche Erinnerungsorte.Annäherungen an eine deutsche Gedächtnisgeschichte (Francfort/Main, 2000).
} 
Irele, A. (1990). The African experience in literature and ideology. Bloomington and Indianapolis: Indiana University Press. Mabe, J. E. (2010). Denken mit dem Körper. Kleine Geistesgeschichte Afrikas. Nordhausen: Traugott Bautz.

Mabe, J. E. (2013). Afrika als Erinnerungsort und Erinnerungsarbeit: eine philosophische Perspektive. In J. Z. Francfort (Ed.), Kein Platz an der Sonne. Erinnerungsorte der deutschen Kolonialgeschichte (pp. 487-501). Campus Verlag.

Mabe, J. E. (2014). Anton Wilhelm Amo and the intercultural background of his philosophy. (J. O. Oguejiofor, Trans.). Nordhausen: Traugott Bautz.

Martin, T. (1985). Pan-African connection: From slavery to Garvey and beyond. Dover: The Majority Press. 